\title{
Bringing History Forward: Learning from Historical Context when Translating Contemporary Health Evidence into Planning Practice
}

Journal of Planning History I-25

(C) 2020 The Author(s) Article reuse guidelines: sagepub.com/journals-permissions DOI: 10.1 I77/I5385|3220977456 journals.sagepub.com/home/jph

(SAGE

\author{
Greg Paine' ${ }^{\circ}$, Susan Thompson', Jason Prior ${ }^{2}$, Irena Connon ${ }^{3}(\mathbb{0}$, \\ and Jennifer L. Kent ${ }^{4}$
}

\begin{abstract}
We describe an historical review of planning documents related to a newly developing high-density locality in Sydney, Australia. The review was undertaken to support the translational component of a larger project investigating how best to include knowledge and experience from the health disciplines to ensure a way of living not hitherto commonplace in Australia is also health-supportive. This article presents (i) key findings from the historical data; (ii) associated learnings about practice, developed to assist the wider translational objectives; and (iii) observations on the potential for such historical reviews to inform better planning practice more broadly.
\end{abstract}

\section{Keywords}

health, high-density, historical context, policy translation

... If instead planners were to view the city as a living organism, an ecosystem, and the planner was to see [their] primary function as promoting health then [they] would cease being a "mechanic" and would become a "prophet/doctor."1

This article describes an historical review of documents related to the strategic planning of a highdensity brown-field redevelopment area (Green Square) in inner-city Sydney, Australia. The purpose was to assist a larger project (Translating Evidence to Support Planning Strategies for Healthy

\footnotetext{
I City Wellbeing Program, City Futures Research Centre, Faculty of the Built Environment, University of New South Wales, Sydney, Australia

2 Institute for Sustainable Futures, University of Technology Sydney, Australia

${ }^{3}$ School of Social Sciences, University of Dundee, Scotland

${ }^{4}$ School of Architecture, Design and Planning, The University of Sydney, Australia
}

\section{Corresponding Author:}

Greg Paine, City Wellbeing Program, City Futures Research Centre, Faculty of the Built Environment, University of New South Wales, Sydney 2052, Australia.

Email: g.paine@unsw.edu.au 
Higher Density Living - the "Project") that investigates how contemporary research about the nexus between human and environmental health and the shape of the built environment can be better actioned within higher-density developments. For clarification:

- The outcomes of the larger Project itself are not detailed here. These are described in separate reports and papers elsewhere. ${ }^{2}$

- The review of documents was one component of this Project and did not initially start out as an historical study. Rather, it comprised an audit of contemporary planning documents to ascertain the presence of health considerations. However, it quickly became apparent an additional historical dimension would be needed to explain how and why health considerations were included, or not, in these documents and in the planning of the locality generally: just what was happening to motivate or require the practitioners to include, exclude, or simply miss health in their actions? This extended review canvased a range of documents dating back to the early 1900s. In doing so, the appraisal also revealed a wider story about health, society, and urban planning that was of interest in itself.

- This article describes the outcome of this historical appraisal, including some of the subsequent deliberations related to the translational objective of the larger Project. As such, it also supports Freestone and Hutchings' contention of "the relevance of the historical dimension in understanding and planning cities and regions." 3

\section{Background}

The metropolitan area of Sydney is currently undergoing extensive densification, predominantly as a result of government policies aimed at (i) accommodating a growing population as well as a desire, at least by some, for better access to city services and amenities and (ii) ameliorating problems now arising from earlier policies (still being implemented in certain localities) which emphasized a typology of low-density car-based suburbs on an expanding urban fringe. Although now somewhat culturally embedded, this urban form has since been judged to be inefficient on a range of economic, social, and environmental criteria. ${ }^{4}$ This includes a well-researched link with the presence of chronic diseases, particularly those associated with low levels of physical activity and social interaction, and in some cases added stress from high household transport costs (both time and financial). ${ }^{5}$ As Leeder and Ward have reflected, in relation to such suburbanization, "[i]n the rush to house people, the rest of our lives are often overlooked." 6

Although there is no associated consensus as to an appropriate alternative density of development, the pace of urban consolidation continues. ${ }^{7}$ It means an increasing proportion of the population is now living in a housing form not hitherto common across Australia. Viewed in the context of the unintended health consequences of the earlier low-density suburban typology, this new development process prompts a valid concern, and a dual question: What are the implications, positive and negative, to our health from this move to higher-density housing and How might any negative impacts be addressed?

The Project (completed in early 2020) explores this question via a collaboration between the New South Wales (NSW) government land development agency, Landcom, the University of Technology Sydney, The University of Sydney, and the University of New South Wales. ${ }^{8}$ Landcom has substantial involvement in the planning, design, and delivery of two key precincts in Green SquareVictoria Park (24.5 ha in area, predominantly residential, and dating from the late 1990s) and the Green Square Town Centre (14 ha in area, mixed residential and commercial, and dating from the early 2000s; Figure 1). 


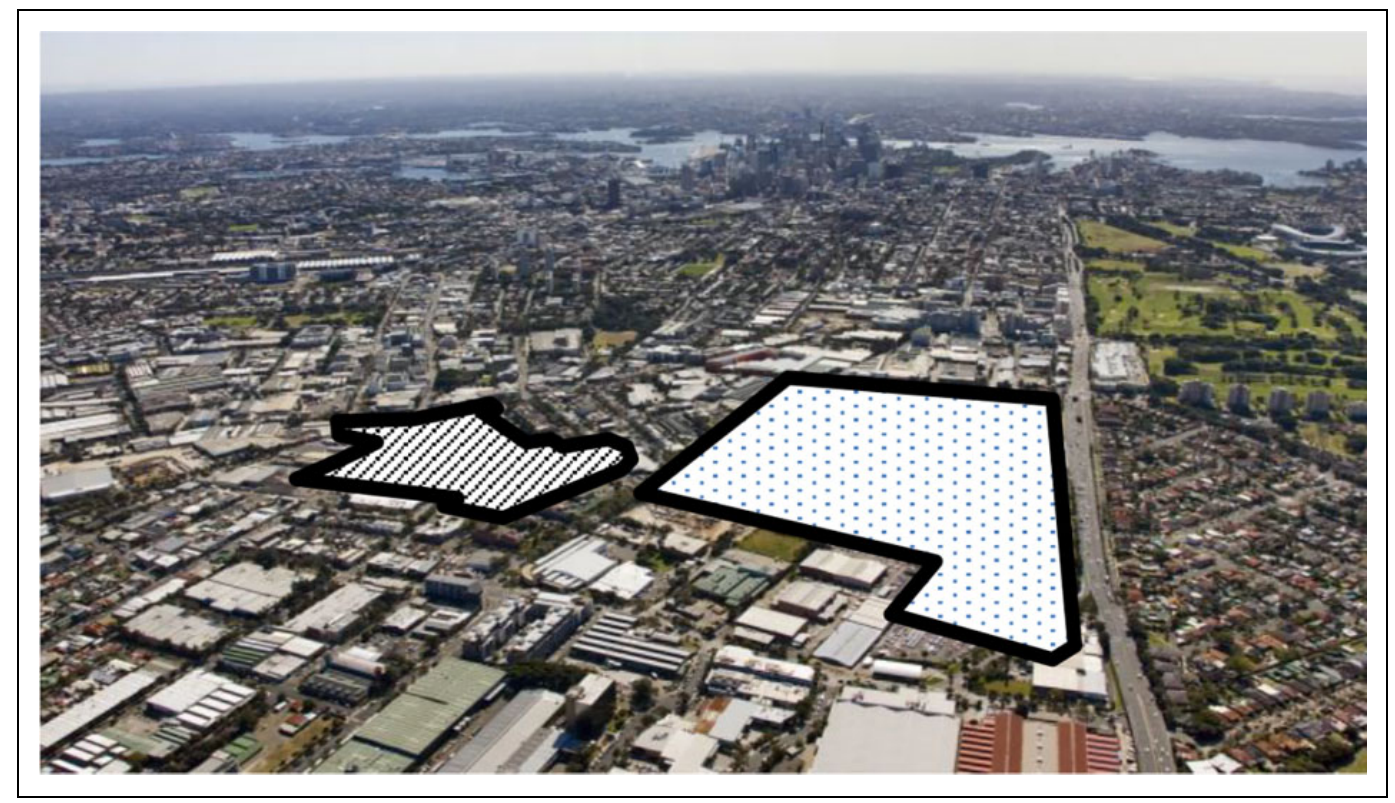

Figure I. Delineation and context of Victoria Park (stiple) and the Green Square Town Centre (hatched). The Sydney CBD is located in the middle distance. Source: Landcom (20I I) Victoria Park (PowerPoint presentation).

The Green Square Redevelopment Area itself comprises 278 ha and was defined in the mid-1990s to capitalize on the opening of a new railway station. The intention is to create a new urban neighborhood of some 30,000 residents and 15,000 workers by 2030, supported by a massive investment in new public infrastructure. Over the intervening years, there have been various changes in local government and state government authorities responsible for the area. Although adding another layer of complexity to the development of the area, these changes are not canvassed here for the sake of brevity.

\section{Research Method}

The initial review of planning documents focused directly on the two precincts in which Landcom is involved and the applicable contemporary planning strategies (the master plans applying to the two precincts and to the larger Green Square Redevelopment Area). However, the number and scope of documents quickly expanded as the range and depth of influences on their content became apparent. There were various elements.

One related to how understandings of health itself have progressed over time, from public, to wider environmental, and now more comprehensive planetary health considerations. Another related to geographical coverage: moving from the two individual precincts to the overall Green Square Redevelopment Area, then to the wider South Sydney locality and local government (Council) area within which Green Square is located, and finally to the metropolitan area of Sydney itself. The chronological focus similarly expanded as the extent of past influences became apparent: from the late 1990s and early 2000s when the precinct master plans were prepared, to a key preceding local planning strategy from the early 1990s (the South Sydney Plan), an influential metropolitan strategy from the 1950s (the County Plan), the various metropolitan strategies adopted since the replacement of the County Plan in 1968 (Table 1), and finally back to the early 1900s for further long-view explanatory background. ${ }^{9}$ 
Table I. Sydney Region Metropolitan Plans (as Prepared by the then Responsible State Government Authority).

$1951-1968$

$1968-1988$

$1988-1995$

$1995-2005$

2005-2010

$2010-2014$

2014-2017

2017-present

\author{
The County of Cumberland Plan \\ Sydney Region Outline Plan \\ Sydney Into Its Third Century \\ Cities For the 21 st Century \\ City of Cities: A Plan for Sydney's Future \\ Metropolitan Plan for Sydney 2036 \\ A Plan for Growing Sydney \\ A Metropolis of Three Cities-the Greater Sydney Region Plan
}

What constituted a planning document was determined from a review undertaken earlier in the Project and was defined broadly to comprise: legislation, policies, master plans, guidelines, land use and building controls, infrastructure proposals, and community development and participation processes and proposals (Table 2). ${ }^{10}$

This range of material also quickly expanded to include internal Landcom documents advising on organizational considerations and values, academic and nonacademic histories and reviews, commentaries by local community organizations, marketing material, and a documentary film. This diversity assisted robustness in terms of identifying possible motivations of practitioners and others, present and past. It also meets, in part, Auster's contention that urban planning histories should maximize the range of voices - and thus experiences - heard and considered. ${ }^{11}$ Material was sourced via references in the primary planning documents, searches in the local council library and archives, key word searches on the Internet, and the lived experience of the lead author as, coincidentally, a resident of the area and a practicing urban planner during some of the period covered.

The review canvased both explicit and implicit references to health and related terms. Related terms included "well-being," "livability," and "sustainable." What comprised an implicit reference required constant assessment. This drew on three existing schemas collating the academic literature on healthy built environments, ${ }^{12}$ plus a more extensive schema (the "Three Theoretical Frameworks of Health") developed earlier in the Project to illustrate the contemporary interplay between public, environmental, and planetary health attributes (Table 3$){ }^{13}$

Various quantitative scores were taken, for example, the number of times a health reference appeared and the number and type of matters considered. This was notwithstanding there was no useful benchmark for such scores. More to the point, the intention of the review was to go well beyond quantitative scoring. The aim was to also obtain a qualitative understanding of the scale of the presence, or not, of health as well as the underlying intention of that presence. Assessments in this regard were recorded against each health reference, together with notes about "fit" with each of the three theoretical frameworks of health defined above.

\section{Observations and Findings}

An initial finding from the review was that health had a varied presence within the different planning documents. In particular, there was a curious "disjuncture" between the South Sydney Plan (1995), which included a strong focus on health, and the Metropolitan Strategy current during its preparation ("Sydney Into Its Third Century", 1988-1995), which did not. Attention therefore turned to the question of how and why. It was at this point that the historical analysis of the wider range of contextual documents was critical.

This analysis identified three key influences on the content of the South Sydney Plan and, by extension, also the subsequent—subordinate—precinct-specific master plans: 
Table 2. List of Planning Documents Reviewed.

\section{Document}

Author/Organization, Date (or the like)

Matters Covered

A. Green Square planning strategy documents

New Southern Railway Environmental Impact Statement

Kinhill Engineers P/L (1994), consultants, for the State Rail Authority of New South Wales

Planning for the Future

South Sydney Council (1991)

The South Sydney Plan

South Sydney Council (1995)

Green Square Structural Master Plan

Stanisic \& Turner/Hassell (1997), consultants, for South Sydney Council

Green Square Infrastructure Strategy and Plan

South Sydney Council/City of Sydney

Victoria Park Master Plan

Landcom (1998)

Green Square Town Centre Master Plan

LFA (Pacific), consultants, and Landcom, for the South Sydney Development Corporation (2003)

Green Square Town Centre: Diary of a Competition. South Sydney Development Corporation (2002)
Concentrates on broad structural land use planning matters. Includes reference to the preceding New Southern Railway Urban Planning Strategy (New South Wales Department of Planning, 1994).

Initial discussion paper to precede The South Sydney Plan.

- Strategy for a Sustainable South Sydney 1995

- South Sydney LEP 1997

- South Sydney DCP-Urban Design 1997

Initial master planning for the overall Green Square Redevelopment Area.

Specific to the infrastructure needs and planning of the Green Square Redevelopment Area. It is continually revised as development proceeds.

Initial master planning for the Victoria Park precinct within the Green Square Redevelopment Area.

Initial master planning for the Town Centre precinct within the Green Square Redevelopment Area. Includes 13 supporting/contributory studies.

Relates to an international design competition for the Town Square component of the Green Square Town Centre precinct.

B. Landcom documents relating to Victoria Park

Victoria Park Zetland (2005)

Untitled briefing note (c. post-2003)

Summary of Board Papers (1997-2007.)

A Review of the Victoria Park Development, Zetland 1997-2010 (2010)

Contaminated Site Summary Audit Report (1999)

Victoria Park Residential Contribution Credit Deed (2007)

"Victoria Park Zetland" (n.d.).

Proposed website home page (n.d.)

"The Water Cycle" (n.d.)

"Start a resident group" (n.d)

"Free Christmas BBQ" (2006)

"Victoria Park Life. Spring edition 2006" (2006)

Notes re-presentation to South Sydney Development Corporation (n.d.)

Independent Architect Review (2009)
PowerPoint presentation.

Briefing note summarizing the history of development processes.

Summaries of Landcom Board deliberations.

Internal review report following completion (report + PowerPoint presentation).

Internal briefing of the auditor review of the site decontamination/remediation plan.

Agreement with the local council regarding reimbursement provisions for public domain works.

Draft marketing images and wording.

Draft home page for proposed marketing website.

Description of proposals for the treatment and disposal of stormwater.

Draft notice for inclusion in resident newsletter.

Post card advertising a "free Christmas BBQ."

Edition of the "Victoria Park Life" newsletter to residents.

Note regarding matters to raise with South Sydney Development Corporation about infrastructure.

Assessment by consultant architects on a residential development proposal within the precinct. 
Table 2. (continued)

Document

Author/Organization and Date

Matters Covered

B. Landcom documents relating to Victoria Park

“Victoria Park: Sustainable Urban Development" PowerPoint presentation to university students. (20II)

Victoria Park (n.d., c.2004)

"Welcome to Victoria Park the natural neighbourhood” (2008)

Document describing the development process and features of Victoria Park in professional terms.

"Fact sheet" describing the development process and features of Victoria Park, primarily in marketing terms.

C. Landcom documents relating to the Green Square Town Centre

Planning Proposal-Town Core Sites within Green Square Town Centre (2010)

Town Core Sites: Statement of Community Benefits and Contributions (n.d.)

Green Square Urban Renewal Area Updated Transport Management and Accessibility Plan (Main Report; 2012)

Your Green Travel Guide-Green Square (2018)

Position Description-Place Manager, Green Square Town Centre (2016)

Green Square Placemaking Framework (n.d.)

Green Square Place Strategy-Creating Great Spaces for Life (n.d.)

GSTC Placemaking Workshop (2017)

Green Square Town Centre Early Activation Strategy (2016)

Green Square: The Social Corner Activation Brief (2017)

Green Square Activations \& Events (n.d.)

Green Square Summer Festival Plan (2017)

Green Square: Placemaking Plan (2018)

Sites 5A \& 5B Green Square Town Centre Redevelopment: Design Report (2014)
Planning report as part of an application to the local council to support revised planning controls.

Statement about contributions to community infrastructure and well-being from the development.

Report by New South Wales government transport authority assessing the transport implications of the development.

Information pamphlet for Town Centre (and wider Green Square) residents and workers.

Advertisement for the place manager position required by the planning approval for the Town Centre.

Document by the local council detailing background, priorities, and proposed "placemaking" actions.

Presentation document relating to Landcom's "placemaking" and "activation" responsibilities.

Summary of outcome: ideas, priorities, and "next steps."

Presentation about proposals for initial Town Centre social and commercial "activation" actions.

Brief for proposals to establish Landcom's "The Social Corner" community space.

PowerPoint presentation describing past activities.

Presentation on proposed publicity, events, and budget.

Presentation describing intended activities of the (appointed) Town Centre Place Manager.

Planning report for the first major Town Centre development.

LEP: local environmental plan; DCP: development control plan.

- a distinct South Sydney experience as a local community;

- an apparent continuing cultural desire within the broader community for a green, low-density suburban ideal (with fortuitous health co-benefits); and

- a then concurrent professional zeitgeist that was exploring new approaches to public policy and with an interest in composite outcomes.

The analysis of Landcom documents also suggested that the two latter-broader-matters were also influential within that organization and therefore also on the content of the precinct master plans prepared by Landcom.

The following subsections detail these four findings. 
Table 3. Summary of the "Three Frameworks of Health" (after Connon et al. 2018).

\begin{tabular}{|c|c|c|}
\hline & Attributes & Description \\
\hline $\begin{array}{l}\text { (I) Global public \& } \\
\text { population health }\end{array}$ & $\begin{array}{l}\text { I.I Global-challenge responsive } \\
\text { I.2 Promotes positive physical } \\
\text { health } \\
\text { I.3 Promotes positive mental } \\
\text { health } \\
\text { I.4 Focused on long-term } \\
\text { health outcomes }\end{array}$ & $\begin{array}{l}\text { The health of urban populations is challenged by increased } \\
\text { pollution, noise, overcrowding, and stress resulting from } \\
\text { the urbanization process and cannot be overlooked } \\
\text { within urban planning. Deals with health in terms of the } \\
\text { wider global challenges that then influence population } \\
\text { health at a local level-by taking a multi-scaled global- } \\
\text { local approach to health improvement actions. }\end{array}$ \\
\hline $\begin{array}{l}\text { (2) Socio-ecological } \\
\text { determinants of } \\
\text { health }\end{array}$ & $\begin{array}{l}\text { 2.I Livability } \\
\text { 2.2 Positive physical health } \\
\text { 2.3 Positive mental health } \\
\text { 2.4 Health equity }\end{array}$ & $\begin{array}{l}\text { Good health outcomes are supported by highly livable } \\
\text { places with good services such as active transport and } \\
\text { are safe, attractive, and easily accessible. Understands } \\
\text { the importance of a "pathway" approach to achieving } \\
\text { good health-by ensuring equitable access to andlor } \\
\text { limiting exposure to the range of social and } \\
\text { environmental causal factors, singly and combined. }\end{array}$ \\
\hline $\begin{array}{l}\text { (3) Planetary health } \\
\text { (relational } \\
\text { ecology) }\end{array}$ & $\begin{array}{l}\text { 3.I Co-benefits approach to } \\
\text { human and environmental } \\
\text { health } \\
\text { 3.2 Holistic approach to human } \\
\text { well-being } \\
\text { 3.3 Addresses global health } \\
\text { challenge especially climate } \\
\text { change } \\
\text { 3.4 Promotes planetary } \\
\text { sustainability in built } \\
\text { environment design }\end{array}$ & $\begin{array}{l}\text { Comprises a renewed focus on the health and sustainability } \\
\text { of the natural environment as fundamental for ensuring } \\
\text { long-term human health, within an overall multiscaled } \\
\text { transformative approach and comprising } \\
\text { multidimensional feedback loops between ecological } \\
\text { health, human health, and the design of urban } \\
\text { environments. }\end{array}$ \\
\hline
\end{tabular}

\section{Health Has a Varied Presence, and Sometimes Does Not Appear At All}

The review of the precinct master plans found that although they included a range of healthsupportive features, health was only rarely given a specific mention. Mostly, the presence of health was more through good fortune than design - mainly as a co-benefit arising from actions prompted by other concerns prominent at the time. Examples of these concerns include ecological sustainability, reduced dependency on transportation by private car, placemaking, and livability. Coincidentally, many of these matters also fortuitously figured in the then social milieu and thus also fitted well with marketing objectives, and a feature of many of the internal Landcom documents is the close nexus between design/development, finance, and marketing considerations.

Where explicit mentions of health were made, they were also usually quite focused. Examples include reference to the necessity for eye health to provide opportunities for long views as relief from close-up work, that cycling is good for health (but with no reference to the similar benefits of walking), and that natural ventilation improves air quality (but the reason for including a requirement for low-emission paints only references wider pollution rather than direct human health concerns).

Another characteristic of these mentions was also of interest: they were often made almost in passing. This, combined with their limited focus, led to a sense that their inclusion was likely a result of the author's own personal interest or experience rather than any broader prompt. Nevertheless, these inclusions do, positively, suggest the author was indeed, at least in part, thinking directly about the well-being of future populations and exemplify, also in part, the vision at the start of this article of practitioners working more "empathically" and less "mechanically." 
An empathic approach was more unashamedly up-front in two key earlier plans: the local South Sydney Plan (1995) and the metropolitan-wide County Plan of some forty years earlier. What was instructive about these two plans was the way in which they appeared to be infused with an intention to deal directly with health issues. The South Sydney Plan responded to the direct experiences of the local community (A Distinct South Sydney Experience as a Local Community subsection) and the County Plan to wider urban issues, particularly, at the time, slum housing. ${ }^{14}$ Both plans expressed the concerns in terms of direct lived experience, not just via statistics.

The difference in empathic and mechanical approaches became particularly obvious when reading the County Plan in parallel with its 1968 successor, the Sydney Region Outline Plan (SROP). ${ }^{15}$ The County Plan includes openly expressed concerns about the health and amenity of the city's residents. The SROP, by contrast, included no similar commentary, suggesting a fundamental detachment. It is evident, for example, in ranking the section on "slum clearance and displaced population," a key focus in the County Plan, after sections on population projections, employment, development of commercial centers, and open space and also in the observation that "The County Plan could not, in itself, bring about a widespread rise in housing standards. The main reason why people were living in sub-standard dwellings was that they could not afford anything better."16 Instead, the SROP focussed on the phasing of release areas on the metropolitan fringe based around an unstated vision of low-density and car-orientated suburbs. ${ }^{17}$ Although it also needs to be acknowledged here that this vision was at the time seen to be inherently healthy (A Continued Desire for a Green, Low-density Suburban Ideal subsection), it is still the case that neither this vision, nor any other health issue, was explicitly stated in the Plan itself.

The result has, in part, generated the current urban consolidation imperative, first given emphasis in the Metropolitan Plan of $1995 .{ }^{18}$ It was also not until 1995 that health again received any specific mention in metropolitan strategies (other than for hospital infrastructure). However, this mention was still only implicit, via "proxy" goals of livability, environmental quality, and equity. Health was not given explicit reference again in a metropolitan plan until 2010, ${ }^{19}$ some fifty years and four plans after the County Plan, except for a passing reference in $2005 .{ }^{20}$ This was to a co-benefit from the promotion of active transport to reduce air pollution, itself an implicit health concern: "The more people walk, cycle and take public transport, the more community physical and mental health improves." ${ }^{21}$ The 2010 plan included a "Direction," one of twenty-two, to "Create healthy built environments," with intentions to "[d] esign and plan for healthy, safe, accessible and inclusive places" (but stated late in the document, on page 208) and to build at least 80 percent of new dwellings within walking distance of centers and public transport. The value of this Direction is acknowledged. However, there is also a concern that being referenced under a separate heading risks health being seen as yet another, and potentially competing, matter for consideration rather than, as exemplified in the earlier County and South Sydney Plans, something that determines the whole orientation of the plan itself.

\section{A Distinct South Sydney Experience as a Local Community}

The second identified influence on the inclusion of health-related matters within the planning of Green Square was a long-standing active engagement by the local community in its own welfare and largely as a result of its hitherto less than privileged background. Five particular experiences were identified.

(i) A low socioeconomic status and residential quality

Until recently, South Sydney has been a long-standing “working-class" locality, with low levels of income, educational attainment, and home ownership. ${ }^{22}$ In addition, its inner-urban location comprised a close-knit mix of industrial activities and attached housing. Although this allowed for 
reduced journey-to-work times (a health benefit), the combination of pollutants, inadequate sewerage and open space, substandard construction, and low socioeconomic status meant this "highdensity" living also resulted in conditions that were, as viewed at the time, '. . not only physically repulsive, but dangerous to human health. ${ }^{23}$

Early health and amenity issues arising from industrial "smoke nuisance" 24 continued as recently as 1972 with the construction, against resident protests, of a waste incinerator on what is now the Town Centre. These protests continued until its closure in 1996, which was seen as a positive outcome of the then Green Square redevelopment proposals. ${ }^{25}$

\section{(ii) Displacements from slum clearance}

Many of these localities were identified for nonvoluntary slum clearance in the County Plan. ${ }^{26}$ Although such clearances addressed issues directly related to living in poor quality dwellings, it failed to recognize the detrimental social and psychological effects of displacing long-standing communities as well as the equally fundamental need to address residents' poverty. ${ }^{27}$ Looking back, these failures are somewhat ironic, given the otherwise considerable attention in the County Plan to health matters. They are though further evidence of the range of ways in which health-and its determinants - are viewed and given emphasis, or not, at different times.

South Sydney also experienced the last of these proposals, in Waterloo, near to Green Square, in the 1970s. The intended replacement development included high-rise buildings. ${ }^{28}$ This time, however, the local residents protested, supported by a (controversial) work ban by the then socially and politically active - and somewhat maverick - union of building workers (the BLF). These actions forced a lower-scale rehabilitation alternative. ${ }^{29}$ Arguably, this experience was still within the memory of many residents and the local council when the South Sydney Plan was prepared in the 1990 s - and as such would have influenced its adoption of a lower density and more medium-rise typology, elements of which are evident in the initial Green Square master planning.

(iii) The density debate

It was recognized at state government level that, in the cleared inner urban "slums," the replacement housing needed to comprise multiunit buildings in order to maintain densities in this highly accessible location as well as provide previously missing open space and community facilities. However, opinions differed about appropriate form. Early twentieth-century developments were low scale, including some based on the Garden Suburb model. ${ }^{30}$ Later, in the 1950s, a high-rise Modernist typology was adopted, comprising "isolated towers and slabs of housing ... in park-like settings . . . at odds with its context." ${ }^{31}$ However, this model was not necessarily any more dense. ${ }^{32}$ In South Sydney, the fourteen-story Northcott Flats built in 1961, for example, had only one-third the population density of the nearby three-story Strickland Flats constructed in 1914 and comprising 71 apartments, eight shops, balconies for each dwelling, and a roof-top communal area. ${ }^{33}$ The Northcott Flats were referred to as "suicide towers" in the BLF and resident objections to the similar scale of development proposed in Waterloo in the 1970s. ${ }^{34}$ Press commentary described a "high-rise low-rise battle," and the then BLF president argued for "cluster-type housing ... with ... retention of green area and a general aesthetic consideration over high-rise living." 35 These views were supported by dual concurrent actions elsewhere in the inner city during the 1970s which demonstrated that existing attached but low-scaled housing could be made healthy via appropriate physical changes: federal government rehabilitation projects in two nearby suburbs ${ }^{36}$ and more widespread privately funded gentrification. ${ }^{37}$ Again, these direct lived experiences arguably influenced the choice of a lower-scale development typology in the subsequent South Sydney Plan. 
(iv) A history of activism and community services

The South Sydney community includes a long history of grassroots activism and as the recipient of often new and innovative social services, many with public health objectives. More generally, Jakubowicz records that, in the 1970s, the inner city became a site of "convergence" of various local, national, and international movements related to community participation, housing, and public services. He further suggests that the results continue to influence present-day planning, specifically the inclusion of community participation processes and an emphasis on equity in the provision of services. $^{38}$

These earlier examples include the following:

- the first baby health clinic in Australia, established in 1914, and an early "demonstration" kindergarten, established in 1940 (and still operating). ${ }^{39}$

- the establishment in 1974 of a "Regional Council for Social Development" by local residents as part of a national government program. This organization still operates (minus national funding), with a stated interest in the "intersection of welfare, community and environmental issues. $" 40$

- collective resident protests, including against an open sewer in the 1890 s, the high-rise public housing proposals in the 1970s, the waste incinerator, and campaigns for Aboriginal civil rights. $^{41}$

A current continuation of this activism can be seen in the local council involvement in providing a local school by offering land it owns, even though education is not a local authority responsibility. This was prompted by a recommendation in a health impact study of the overall Green Square development. This study looked in particular at impacts on children, a matter not included to any great degree in the master plans and previously identified health benefits of attending a school within walking distance. ${ }^{42}$

\section{(v) Gentrification}

Most of the proposed slum clearances did not occur. Public funding was invariably limited, ${ }^{43}$ and new tenancy legislation in 1948 resulted in many owners selling to their tenants (with homeownership often a favorable health outcome in itself), making resumptions more difficult. ${ }^{44}$ There was also growing acceptance that the existing housing had an intrinsic worth, in particular by a new class of residents seeking to live near city center employment and services, and with the resources to carry out building alterations. ${ }^{45}$ This process was also encouraged by reductions in both industrial emissions (due to progressive regulation) and overall population density. ${ }^{46}$

Such "gentrification" had various and ongoing health implications, positive and negative. These include the following:

- improvements in the heath and general amenity standards of the dwellings themselves; ${ }^{47}$

- the displacement of often long-term but less economically resourced residents, resulting in a loss of social networks and community; ${ }^{48}$

- an increase in local levels of inequality; ${ }^{49}$

- an inflow of resources which assisted some of the activism already present, particularly against high-rise redevelopments; ${ }^{50}$

- the introduction of a suburban ideal that sought more open space and quieter streets (subsequently embedded in the later 1990s strategies - see A Continued Desire for a Green, Lowdensity Suburban Ideal subsection); 
- the inclusion of a levy in those subsequent strategies to finance the provision of "affordable" housing units as a way to offset the loss of earlier low-cost housing; and

- access by this new population to an intrinsic health-supportive local urban form with its walkability and incidental socialization, perhaps also demonstrating the viability of this experience to a wider constituency familiar only with a more suburban typology.

\section{A Continued Desire for a Green, Low-density Suburban Ideal}

Another aspect of the density issue - a lingering cultural and health-related preference for the individual detached house-played out only partially in South Sydney. It does though still influence its contemporary planning. The 1909 inquiry into the planning of Sydney (see Note 14) argued that on "social and hygienic grounds... workmen [and their families] should be encouraged to live in separate houses in the suburbs." ${ }^{51}$ Consistent with this view, it has been noted that even though the Strickland Flats (mentioned above) provided amenities not usually available in the slums (private bathrooms, lavatories, rooftop laundries, and gardens), "in the public's mind," location in a new garden suburb developed at a similar time but some distance away was still preferred. ${ }^{52}$ Such preference was reinforced by an influential 1945 polemic, Houses in the Sun by architect Walter Bunning, which contended that the detached house with private garden provided the healthiest mode of living and an antidote to the inner cities where children had to "play in lanes and alleys" and parents "[sat] on their doorsteps" to socialize. ${ }^{53}$ This vision generated the low-density "sprawl" that characterized Sydney's growth following the replacement of the County Plan in 1968. However, as noted, the overall health benefits have proved elusive. Somewhat ironically, a number of public housing estates constructed in this format are now being reconfigured: a twenty-first-century variation of the twentieth-century slum clearances. ${ }^{54}$

The ambivalence to multiunit housing is well illustrated in Sydney's 1968 Metropolitan Plan. On the one hand, the Plan did note the then embryonic process of gentrification, stating:

... some old houses have... been rehabilitated by people who prefer a home close to the City ... the terrace house, once despised, is being recognised as an appropriate form of high density development, providing greater privacy than a home-unit (apartment) and, in addition, a small backyard. ${ }^{55}$

However, the Plan took this no further, choosing instead to promote the entirely different typology later described as "auto-suburbia." 56

So, it was interesting to find that the South Sydney Plan included an explicit, almost bold, reversal of this cultural predilection, revaluing the existing local terrace house and mixed-use typology and consistent with those "people" identified in the quote above some twenty-seven years earlier. This revaluing is illustrated, for example, by the inclusion of a drawing citing "the street [as] a most important component of inner-city life" (Figure 2) and by commentary that "The nature of inner Sydney encourages travel on foot or bicycle. Pedestrians contribute to the vitality of the area and its shopping, commercial and entertainment facilities ...." ${ }^{57}$ Influences for this stance would have been the immediate local community and broader zeitgeist prompts (A Distinct South Sydney Experience as a Local Community and A Concurrent Professional Zeitgeist that Explored Composite Outcomes subsections). One could also easily speculate another prompt was the advocacy of this more "traditional" pattern by urban activist Jane Jacobs in her then widely read and influential critique from the 1960s of (sub)urban(ization) processes in the United States. ${ }^{58}$ Also relevant here is the inclusion in the later Green Square precinct master plans of employment spaces. The aim is to reduce both the environmental and health impacts of long journey-to-work times for residents, a persistent 


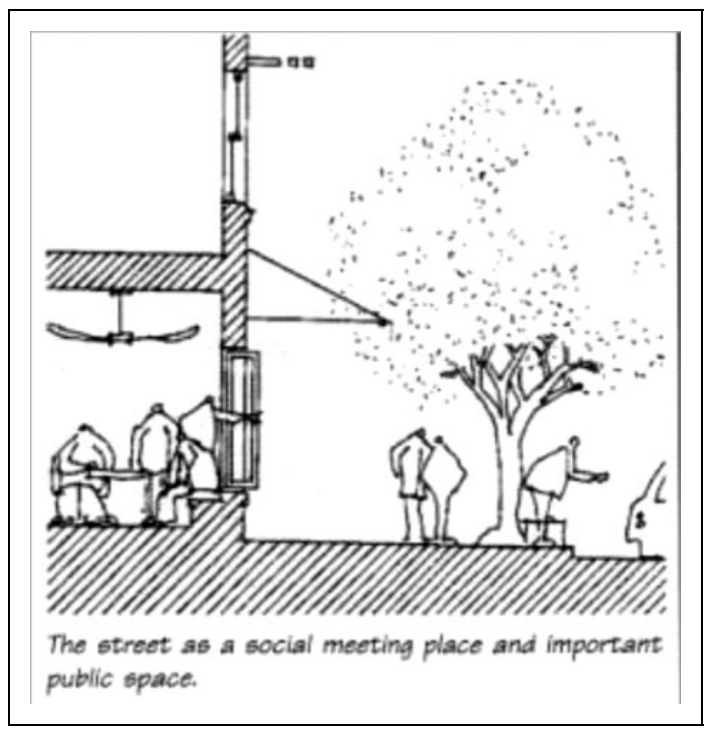

Figure 2. The street as social space. Source: South Sydney Development Control Plan 1997—Urban Design, 21.

concern identified since the early 1900s, and exacerbated by the separated land-use typology that characterizes the "auto-suburbia" model. ${ }^{59}$

There is also a further element of this suburban-urban "tension"-a "relocation" of the suburban ideal into the inner city as part of gentrification and brown-field redevelopment processes. It is manifest in changes to the existing urban form to increase green open spaces and separate land uses still seen as too different and all part of a desire to be close to the city center but without its earlier "crowding" and "dirt." 60 Elements of this process can be detected in the South Sydney Plan and subsequent precinct master plans. These include relatively low maximum density provisions (at least as initially proposed), describing the developments as new "suburbs," "neighbourhoods," and "villages" rather than, say, a "new town" or part of a "city center," restrictions on traffic, and proposals for extensive avenue street-tree plantings and "landscaped precincts with suburban character" including, in Victoria Park, its marketing as "a traditional leafy Australian suburb." The longevity of these ideas is also well illustrated by almost exact wording in a description in the Victoria Park master plan of the overall layout, and a reference in the County Plan, exactly fifty years prior, to a new model housing estate, also in South Sydney, as comprising "well-designed flat blocks, surrounded by gardens insulated from through traffic."

\section{A Concurrent Professional Zeitgeist that Explored Composite Outcomes}

Green Square has benefited — via its various strategic planning documents - from a set of innovative orientations developed within the planning and decision-making community in the preceding years, broadly the 1970s, 80s, and 90s. Considered together, they display an overall interest in forging interconnections across sectors and disciplines. This interest is encapsulated, for example, in the "triple bottom line" - social, economic, and environmental - accounting process, first conceived in the 1990s. ${ }^{62}$ It is also present in the view, within the then developing approach of environmental health (vii, below), that "health as a reductionist science needs to be abandoned."63 
It appears to have been an interesting period. Freestone, for example, notes a "popular and professional questioning of conventional planning priorities" in the $1970 \mathrm{~s} .{ }^{64} \mathrm{We}$ identified eight elements of interest discussed below.

Here also a caution: the reader needs to remember this is an historical review. Many of these elements are now embedded in practice, and no longer given explicit mention. It is also useful to note the observation that there are invariably time lags - some short, some long - between the development, dissemination, and pervasive uptake of new ideas and approaches. ${ }^{65}$

(i) A new legislative focus

In 1979, new state-level legislation (the Environmental Planning and Assessment Act) substantially reorientated planning practice; epitomized in the change in title from "town" to "environmental" planning. Although there was no specific mention of health in this legislation, it could be said to be intrinsically covered in its (new) explicit objective to "promote" the "social and economic welfare of the community." Included also was also a new emphasis on community participation. This would have particularly resonated with the South Sydney community. Freestone suggests the new provisions in this regard were a direct outcome of the BLF work bans and resident action group movements in the 1970s. ${ }^{66}$ These frequently played out in South Sydney. The development of a new planning strategy under this legislation was an early decision in 1990 by the then new South Sydney Council, which had a strong resident orientation. ${ }^{67}$

(ii) A focus on "integrated" planning

The concept of Integrated Local Area Planning (ILAP) was another influence. This was promoted in the 1990s by the Australian Local Government Association. The aim was to improve integration across all of a council's activities as well as with all levels of government. ${ }^{68}$ This reform was a longstanding need. The County Plan, for instance, gave considerable attention to a lack of intergovernment coordination ${ }^{69}$; and the demise of the Plan in 1968 has been attributed to an inability to resolve this matter. ${ }^{70}$ The South Sydney Plan adopts the intention of ILAP in that it references Council's responsibilities across several areas, not simply town planning. Consultants preparing an early strategy for Green Square commented - favourably - that "In format and content [the Plan more] resembles metropolitan plans at the State Government level."71

In NSW, ILAP was essentially superseded by similar whole-of-council "integrated planning and reporting" (IP\&R) provisions in the new Local Government Act 1993. These provisions require each council to prepare a Community Strategic Plan and accompanying resourcing strategy, a delivery program (which includes town planning controls), an annual operational plan, and regular progress reports. Consistent with these objectives, the South Sydney Plan included a comprehensive "Implementation Plan" across the whole of Council. In addition, the then (State) Premier's Council for Active Living published a guide for the inclusion of health matters in the IP\&R process. ${ }^{72}$

(iii) Place management

The 1990s also saw an emphasis on "place" as a way to address the deficiencies in urban management, in particular: (i) a lack of agreed and clearly stated intended outcomes and (ii) difficulties in achieving such outcomes given responsibility is usually split between professional groups and even organisations. ${ }^{73}$ Statements as to "desired future character" are now commonly used to address the first matter. ${ }^{74}$ The South Sydney Plan includes such statements for the various Green Square precincts. A requirement that initial "master plans" be prepared is in effect also a place management initiative. Specific "place managers" have been introduced to address the governance issue. In the 1990s, the NSW Premier's Office appointed a number of managers in localities 
experiencing long-term social welfare issues including two in South Sydney. ${ }^{75}$ The South Sydney Development Corporation, created in 1996 for the then Green Square Redevelopment Area, is an example of place management via a dedicated state government agency (though now disbanded). ${ }^{76}$ Currently, the Town Centre Master Plan includes the establishment of a precinct place manager with a dedicated budget, and the City of Sydney appointed its own Green Square Place Manager in 2015.

(iv) Sustainable development

The focus on integrated development paralleled, at the time, attention on the concept of "ecologically sustainable development" (ESD). ${ }^{77}$ ESD is now widely embedded within public and private activities following the 1992 United Nations Earth Summit and resultant "agenda for the 21st century." Although South Sydney Council did not adopt a Local Agenda 21, the influence of ESD can nevertheless be seen in South Sydney being one of the first councils to adopt a policy to address the "greenhouse effect" (in 1992) and in the inclusion of "sustainable" in the title of the strategy component of the South Sydney Plan. In his introduction to that Plan, the Mayor made specific reference to the importance of ecological sustainability, referencing the considerable (new) environmental content in the Plan, and Council strategic planners presented a paper to the "Rio +5 Years" Conference in 1997 on the work by Council in this regard. ${ }^{80}$

Sustainable development was also an important influence in Landcom's policy development. In 1996, the organization adopted energy-efficient and "ecologically responsible" practices in its housing developments. In addition, legislation in 2001 to establish a new corporate structure included a mandatory objective that all operations be conducted "in compliance with the principles of ecologically sustainable development."

\section{(v) Healthy Cities}

The World Health Organization's (WHO) Healthy Cities Program was another zeitgeist influence at the time. Established in 1986, the Program aimed to embed health into all existing urban management, expenditures, and governance activities, within a vision of the city as providing an overall "cradle" of good health rather than simply health-supportive infrastructure. ${ }^{81}$ In Australia, the Healthy Cities Program was jointly promoted by the national associations relating to community health and to local government and the then Australian Commission for the Future. ${ }^{82}$ A subsequent series of national Healthy Cities conferences is still held under the title Making Cities Liveable. The South Sydney Plan recommended development of, variously, a "Healthy City Policy" and a local "Health Plan" (not implemented) and, unusual for local government at the time, a "food policy" 83 (adopted in 1995 to address local availability of healthy, affordable food). The Healthy City Model developed by Hancock, one of the instigators of the Healthy Cities movement, has been used as the basis for Landcom's subsequent Healthy Development policy. This Policy merges community, environment, and economic matters to achieve a stated "sustainability $=$ health" objective. ${ }^{84}$

(vi) A re-visioning of environmental health

The Healthy Cities movement and associated WHO Charter on Public Health (also adopted in 1986) prompted public health disciplines to refocus on the nexus between human and ecological health (see also Table 3). ${ }^{85}$ One result was a change in the role of local government health "surveyors" from predominant regulation to include broader environmental actions, often also with a change in title to environmental health officers. In Australia, a National Environmental Health Strategy launched in 1999 proposed the establishment of Community Environmental Health Action Plans. These aimed to "manag[e] place-based economic, social and environmental risk, and re- 
establish[...] human/environment sustainability" (emphasis added). ${ }^{86}$ This expansion of perspective is evident in the (then) unusually wide-ranging list of matters to be addressed in the recommended South Sydney "Health Plan." Proposed actions included making walking and cycling more attractive, improving nutrition, increasing shade tree cover to address melanoma risk, providing affordable housing, and generating employment. All actions are evident in the subsequent Green Square precinct plans (and their implementation) though, as noted earlier (Health Has a Varied Presence, and Sometimes Does Not Appear At All subsection), without necessarily referencing a specific health connection.

(vii) Urban design

The 1980s also saw a resurgence of interest in urban design. This was prompted by concerns about a growing "placeless-ness" in contemporary development (addressed also in the placemanagement initiatives mentioned above), broader sustainable development issues, and the substantial promotion of "New Urbanism" - an urban design approach developed in the United States. ${ }^{87}$ In 1987, an Australian national Urban Design Forum commenced and published a quarterly newsletter. This was distributed free to local councils. The Federal Government adopted the "Australian Model Code for Residential Development" in 1989. This Code is referenced in the development control components of the South Sydney Plan. As well, the NSW Government legislated a Design Code for residential buildings in 2002. Landcom adopted New Urbanism principles in its work from the mid1990 s, also promoting this approach to local councils. ${ }^{88}$ Experience suggests these principles, which advocate walkability, social connectivity, and mixed land uses, are consistent with the achievement of a health-supportive environment. ${ }^{89}$ The then emphasis on urban design is reflected in the ordering of the urban design provisions in the Green Square precinct master plans first. It is also evident in the attachment of the words "urban design" to the title of the development controls in the South Sydney Plan, even though they cover numerous other matters. Two developments in the Victoria Park precinct have now been included as exemplary resultant outcomes in a subsequent publication reviewing and promoting the 2002 Design Code..$^{90}$

(viii) Safety and security

A final element is the now embedded close collaboration between urban design, policing, and crime prevention actions, under the terminology "Crime Prevention Through Environmental Design" (CPTED). ${ }^{91}$ Instructively for our Project, initial prompts were studies into elevated crime levels in higher-density housing estates in the United Kingdom and the United States. ${ }^{92}$ Another influence was Jacobs' earlier (1961) contention that mixed-use and highly trafficked streets resulted in beneficial levels of informal surveillance and therefore safer environments. ${ }^{93}$

The South Sydney Plan cited undesirable levels of local street crime, theft by break and enter, domestic violence, pedestrian trauma from accidents, and vandalism. Similar concerns were also prevalent broadly across Sydney, leading to frequent press references to "a surging crime wave." 94 In the 1990s, the NSW government established a community safety audit process and "safer by design" guidelines. Both are referred to as requirements in the South Sydney Plan and in the precinct master plans. A later iteration of CPTED promoting community development activities and the acceptance of social diversity ${ }^{95}$ is consistent with the postoccupation social activation programs adopted by both Landcom and the local Council in Victoria Park and the Town Centre. Useful for the translational objectives of this Project, a review of the process of embedding CPTED now over a period of thirty years, also identified various lessons for current health and built environment practice: guiding documents need to be flexible but within a deep understanding of the initial aims (here the health-environment nexus); a need to marshal popular, and hence political, interest; and a need to understand the complexities of both context and interdisciplinary collaboration. ${ }^{96}$ 


\section{Conclusions}

\section{A Divergence and Convergence of Interests}

Our study found an ongoing — and dynamic — connect and disconnect between the two disciplines of health and planning over the period reviewed. This connect and disconnect are similar to what Hensley et al. (2020) refer to as a divergence (and, by correlation, convergence) of interests in their study of another Australian city, Brisbane. That study found a continuation of the postwar situation where, as discussed in Health Has a Varied Presence, and Sometimes Does Not Appear At All subsection, these interests - health and planning - diverged as a result of the suburbanization process assisting the eradication of the earlier prevalence of various communicable diseases as well as leading to improved living environments generally, with the "earlier [more] symbiotic relationship" between health and planning now lost. ${ }^{97}$

Our study however came to a more positive conclusion about the current state of play, finding, overall, evidence also of a continuing convergence of interests, albeit after a period where there was no consideration of health at all. This finding would partly be as a result of the time period studied: the study by Henesley et al. (2020) only canvased the period to 1997, prior to current connections between planning policy and health professionals' concerns over the current prevalence of chronic diseases. However, this does not entirely explain the difference. Our study also found, as detailed in A Concurrent Professional Zeitgeist that Explored Composite Outcomes subsection, a fruitful converging of interests more generally (even though often only as co-benefits) through the 1970s, 80s, and 90s. Here, our study also has resonance with Freestone and Wheeler's international review of planning and health over time - and which similarly revealed a continuing and ongoing duality of connect and disconnect between the two. ${ }^{98}$

That said, Henesley et al.'s (2020) conclusions do still resonate with another more general observation about planning in Australia, found as part of our broader review of commentaries: a lingering lack of value given to the planning process itself. Our findings support, to varying degrees, earlier references to Sydney as an "accidental" city, where "planning" is subservient to "laissez-faire individualism" and the whims of "political agendas," and comprising more an exercise of catchingup with issues only once they arise, 99 to a "planning deficit," resulting in "unintended cities"; 100 and, most recently, to a "negative inertia... affect[ing] urban planning practice generally [in Australia]." " As evidenced in A Distinct South Sydney Experience as a Local Community subsection, Green Square and the South Sydney locality where it is situated have long felt the adverse effects of such processes. More generally, it remains a continuing issue when seeking to translate health (or any other matter) into planning strategies.

\section{A New Skill Base Related to the Complexity of Health and High-density Living}

Many of the documents we reviewed comment that Green Square currently comprises the largest urban redevelopment project in Australia. This scale brings with it its own complexities. There are also numerous compounding issues: location on former wetland, necessary site amalgamations, the remediation of contaminants, a location within an already congested urban corridor, minimal existing community infrastructure, a statutory requirement to provide housing affordable to diverse households, and finally how to finance up-front costs from development contributions obtained spasmodically over an extended period. Further, there is recognition in the Town Centre Master Plan that to be socially and economically successful, the outcome as a whole needs to comprise "a complex urban environment [of] social interaction" (emphasis added). ${ }^{102}$

Considered in conjunction with earlier suburbanization processes, it gives rise to a speculation - that the skills and processes required to develop the planning strategies for localities like Green Square are different, probably fundamentally so, from those needed to achieve the earlier model of low-density, 
car-based, urban-fringe development. Arguably, the well-intentioned approach adopted in the County Plan to address the complexity of a substantial proportion of the population then being housed in innerurban slums with a substantial incidence of disease could be now characterized as an oversimplification. The relocation of the population to "greenfield" developments designed around separated land uses and buildings was made on the basis that the increase in green space and penetration of light and air were inherently health supportive. Figure 3 illustrates the approach. The dilemma is that while this urban pattern was successful in addressing some health issues, it has also generated its own new health concerns (Background section). Indeed, the image in Figure 3 exemplifies one of these in seemingly replicating the physical separation of buildings and uses in the portrayal of the three adults in the shopping center: each pursuing their activities separately, without social interaction. ${ }^{103}$

The scale of the difference in approach now required - and adopted in Green Square-is well illustrated when the two visions are compared (Figure 3). It will be of use for the translational aspects of this Project to investigate further the nature of the different skills and processes at play.

Here, the experience of Landcom will be able to provide useful comparative advice. Landcom's current role in Green Square is as a result of its legislated objective to "... assist the Government in undertaking, strategic or complex urban development projects." However, Landcom also has experience in both typologies: its initial 1986 constitution was to facilitate affordable greenfield development, which tended toward low-density estates with dispersed land-use patterns.

\section{Learning from History}

The historian James Boyce, when writing about the black plague of the fourteenth century in the context of the current (2020) pandemic, describes being "nervous of affirming that there are 'lessons' from history," as is commonly suggested and that instead any learning that might be obtained is through "listen[ing] deeply" of others' experiences rather than copying direct responses. ${ }^{104}$

It leaves a lingering dilemma. We have been conscious that, and although Karskens, also an historian, has noted, that the history of Green Square reflects the history of urban development in Australia generally, ${ }^{105}$ there are also some very local elements to the South Sydney experience that need to be kept in mind. If, for example, the South Sydney Plan had not been so focused on health, would the health-supportive responses in the subsequent precinct master plans have occurred? If the South Sydney community itself had comprised a better-placed socioeconomic class, would its planning strategy have included this content in the first place? And if that community had not had the lived experience of medium-density mixed-use and walkable neighborhoods, would that strategy have explicitly adopted what is now recognized as a health-supportive typology?

That said, it is also worth noting here Freestone and Hutchings' support of "the relevance of the historical dimension in understanding and planning cities and regions," in conjunction also with discussion by McManus about the transference of ideas into effective practice. ${ }^{106}$ Drawing on actornetwork theory (here referencing Callon, 1986), McManus notes the need for concurrent, complementary, processes: (i) a locally orientated "situational" thinking and (ii) a broader scanning beyond local situations in order to learn from experiences elsewhere. Effective uptake of those wider experiences is most likely to occur when transferred contextually, that is, when translated into a specific locally suitable form. ${ }^{107}$ Knowing and valuing each context, or "setting," is therefore critical for sustained beneficial outcomes. ${ }^{108}$ This article illustrates how a review of historical context can reveal the substantial depth and breadth of influences and also at times long gestational periods at play in how and why certain matters might be included in planning strategies. This uncovering, in turn, provides lessons on how to intentionally include specific matters in future strategies.

A further point is worth noting (with our emphasis): Freestone and Hutchings' further comment that historical understandings "can help define precedents, expand humility, and lead to more considered environmental assessments [and] even add a healthy scepticism to the tool kits of 


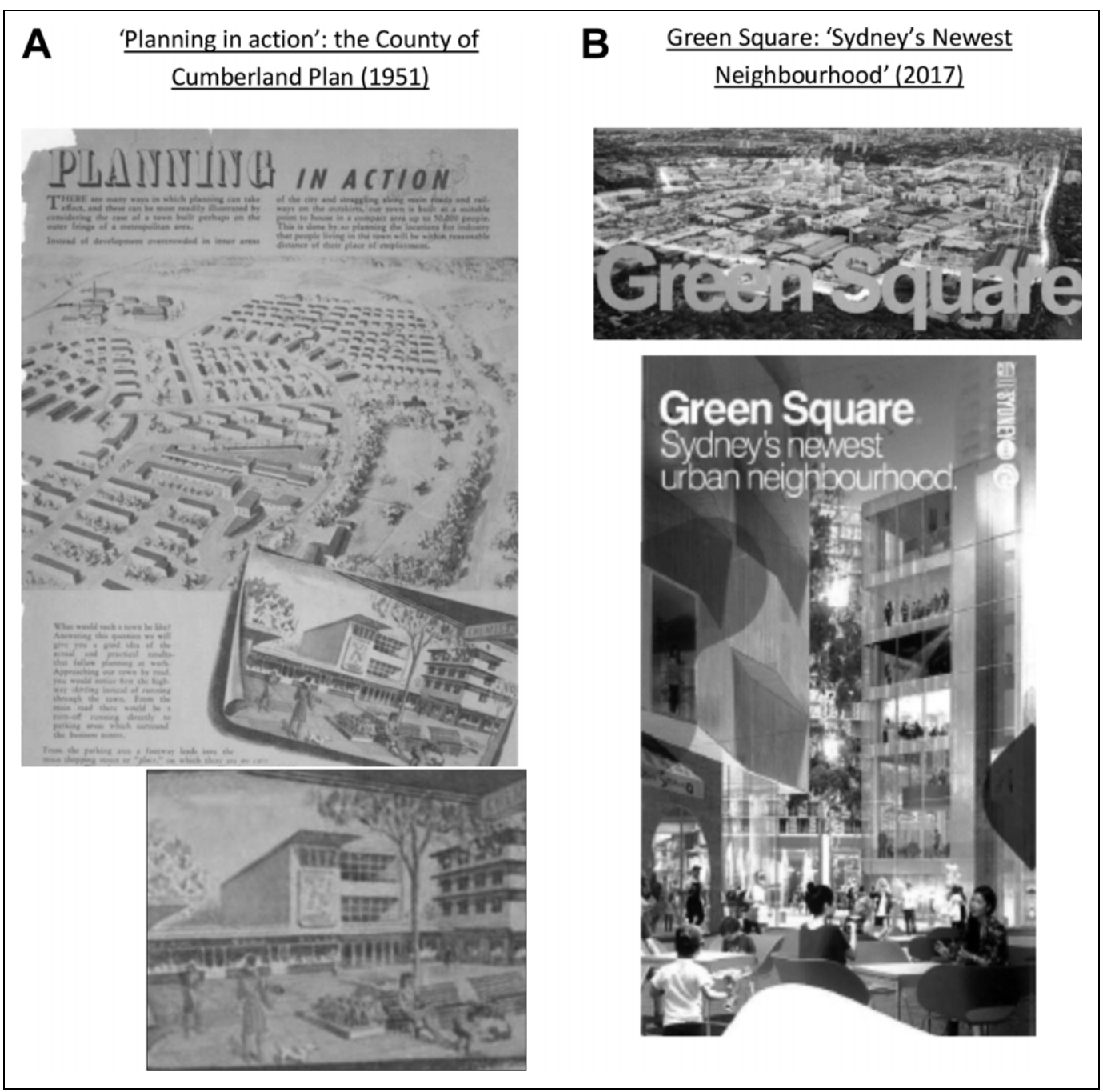

Figure 3. A comparison of urban "visions" and resultant "scale" of complexities. (a) "Planning in action": the County of Cumberland Plan (195I). Source: Cumberland County Council, You and the County Plan (pamphlet, n.d.). (b) Green Square: "Sydney's Newest Neighbourhood” (2017). Source: City of Sydney, Green Square: Sydney's Newest Neighbourhood (pamphlet, 2017).

planning." 109 The reference to humility is of interest when considering another conclusion from our review: that in Australia, the long-standing perception that the detached suburban house is inherently healthy and that, by corollary, denser housing forms are inherently unhealthy have led to a certain planning and broader cultural hubris. It is evident, for example, in:

- a lack of scanning ahead to ascertain, once the problems of the slums and associated communicable diseases were resolved, any other less visible or newly apparent health concerns;

- a substantial period where, by and large, health was not included at all as a specific planning consideration; and

- an ambivalence to and sometimes overall rejection of multiunit housing, resulting in a reduced range of higher density models to now emulate, evaluate, and improve upon. ${ }^{110}$ 


\section{Drawing Lessons for Future Practice}

Finally, our review has drawn the following observations, developed in conjunction with the wider translational objectives of the larger Project in mind.

In relation to the varied presence of health over time, there is a need to establish prompts so that health is continually present (convergent) in practitioners' considerations. This includes potential, not just existing, health issues as well as ways to ensure any initial "burst" of interest in a particular matter is sustained. The encompassing approach of "health in all policies," "111 embedded also within the earlier Healthy Cities movement, may assist. So too might health impact assessment, although this needs to be undertaken before fundamental decisions have been made and adopt a comprehensive view of health and its determinants. ${ }^{112}$

Important insights can be gained from an awareness of the prevailing community zeitgeist/local lived experience. These can be used by practitioners to support and build on health-supportive aspects already present as well as identify potential areas of change to achieve a healthier community. Again, this is consistent with the Healthy Cities model.

Similarly, knowing the existing professional zeitgeist/decision-making milieu can indicate opportunities to include contemporary health considerations, often as co-benefits to existing actions. This means certain initiatives can occur without requiring perhaps difficult initial attitudinal changes. More fundamentally, understanding context might ultimately assist the development of an overall new contemporary zeitgeist that is inherently health-focused. A fundamental - and positive - finding of our review is that such health-focused zeitgeists have been present before, with aspects still apparent within the planning and development of Green Square today.

In relation to the continuing suburban ideal, there are of course different suburban experiences and configurations. Green Square suggests there are health — and market acceptance — advantages from including familiar health-supportive elements of both lower-density green suburban and denser mixed-use and walkable inner-urban typologies. ${ }^{113}$

And in relation to a new skill base able to deal with the complexities of health and high density, there is a need to facilitate ongoing interactions between practitioners and researchers from different disciplines to share knowledge and concerns and then address gaps as they become obvious through practice. Making these practitioners and researchers aware of historical antecedents can illustrate how this is indeed possible. This Project is an example of such action. Fruitfully, the Green Square experience suggests a fundamental interest among the contemporary practitioners involved in actively engaging with the challenges that arise.

\section{Acknowledgments}

The authors acknowledge with thanks the helpful assistance of Professor Robert Freestone of the Faculty of Built Environment, University of New South Wales, in commenting on an early draft of this article and the similarly helpful comments by the two reviewers for this journal.

\section{Declaration of Conflicting Interests}

The author(s) declared no potential conflicts of interest with respect to the research, authorship, and/ or publication of this article.

\section{Funding}

The author(s) disclosed receipt of the following financial support for the research, authorship and/or publication of this article: The historical review of documents discussed in this article is part of the Translating Evidence to Support Planning Strategies for Healthy Higher Density Living research 
project funded by New South Wales Landcom under their research and learning program. The authors are grateful to Landcom for their partnership and support for the completion of this review.

\section{ORCID iDs}

Greg Paine (D) https://orcid.org/0000-0003-2391-3278

Irena Connon (D) https://orcid.org/0000-0001-7770-2172

\section{Notes}

1. D. Engwicht, "The Streets. Common Ground for Cultural Growth," in Common Ground for Cultural Growth: A Slide Kit, Brisbane, Australia, 7.

2. https://www.landcom.com.au/approach/research-and-learning/universities; I. Connon et al. Healthy Higher Density Living: A Review of the Literature (Sydney, Australia: Landcom, 2018); I. Connon et al., What Evidence Is Available to Translate into Planning Strategies for Healthy Higher Density Living? An Evidence Review (Sydney, Australia: Landcom, 2019).

3. R. Freestone and A. Hutchings, "Planning History in Australia: The State of the Art," Planning Perspective 8, no. 1 (1993): 72-91, 73, 83.

4. J. Ohlin, "A Suburb Too Far? Urban Consolidation in Sydney" (NSW Parliamentary Library Research Service Paper, 2003).

5. S. Leeder and M. Ward, "Intelligent Design Crucial for Better Urban Health," Australian Medicine 18(4 September 2006): 14-15.

6. Ibid., 4.

7. For a similar discussion on the experience in the United Kingdom, see C. Boyko and R. Cooper, "Density and Decision-making: Findings from an Online Survey," Sustainability 2013, no. 5 (2013): 4502-22.

8. https://www.landcom.com.au/approach/research-and-learning/universities.

9. The South Sydney Plan (1995), prepared by the then South Sydney Council, comprised an initial discussion paper, a strategy (Strategy for a Sustainable South Sydney) and implementation controls. The County of Cumberland Plan (1951), prepared by the then Cumberland County Council, comprised a strategy, statutory controls, and supporting documentation,

10. Connon et al., What Evidence Is Available, 2019.

11. M. Auster, "Retreat from Babel: Why We Need to Teach Planning History." Planning History Conference (Canberra, Australia: Australian National University, 27-30 June 1995): vol. 2.

12. A. Capon and E. Blakely, "Checklist for Healthy and Sustainable Communities," NSW Public Health Bulletin 18, no. 3-4 (2007): 51-54; S. Thompson and P. McCue, The CHESS Principles for Health Environments: An Holistic and Strategic Game Plan for Inter-Sectoral Policy and Action (Sydney, Australia: NSW Premier's Council for Active Living, 2008); J. Kent and S. Thompson, "The Three Domains of Urban Planning for Health and Well-Being," Journal of Planning Literature 29, no. 3 (2014): 239-56.

13. Connon et al., Healthy Higher Density Living, 2018.

14. Early planning in Sydney was also heavily influenced by the "shock," in 1900, of an outbreak of the bubonic plague. There were a number of responses, including slum clearances, development of public and private "garden suburbs," and the convening, in 1909, of an inquiry into the "improvement of Sydney" (P. Curson and K. McCracken, "In Sickness and in Health: Sydney Past and Present" in Sydney. The Emergence of a World City, ed. J. Connell [Melbourne: Oxford University Press, 2000]: 96-118). A metropolitan-wide council, established in 1945, and subsequent (1951) County Plan were belated outcomes.

15. State Planning Authority of New South Wales, Sydney Region: Outline Plan 1970-2000 A.D. A Strategy for Development (Sydney, Australia: State Planning Authority of New South Wales, 1968).

16. State Planning Authority of New South Wales, Sydney Region: Growth and Change. Prelude to a Plan (Sydney, Australia: State Planning Authority of New South Wales, 1967).

17. H. Stretton, Ideas for Australian Cities (Melbourne, Australia: Georgian House, 1970). 
18. R. Freestone, "Historical Trajectories and Contemporary Debates," in Sydney. The Emergence of a World City, ed. J. Connell (Melbourne, Australia: Oxford University Press, 2000), 119-43.

19. Department of Planning, Metropolitan Plan for Sydney 2036 (Sydney, Australia: Department of Planning, 2010).

20. Department of Planning, City of Cities: A Plan for Sydney's Future (Sydney, Australia: Department of Planning, 2005).

21. Ibid., 31

22. South Sydney City Council, South Sydney Social Plan (Sydney, Australia: South Sydney City Council, 2001).

23. Curson and McCracken, "In Sickness," 103.

24. Cumberland County Council, County of Cumberland Planning Scheme Report. Presented to the Minister for Local Government the Hon. J. J. Cahill, MLA. 27 th July 1948 (Sydney, Australia: Cumberland County Council, 1948), 61.

25. City Plan Heritage, City of Sydney Warehouses and Industrial Buildings Heritage Study (Sydney, Australia: City of Sydeny, 2004).

26. C. Allport, “The Human Face of Remodelling: Postwar 'Slum' Clearance in Sydney," Urban Policy and Research 6, no. 3 (1988): 106-18.

27. J. Flood, "The Case of Sydney, Australia," in Development Planning Unit (DPU) and University College London (eds), Understanding Slums: Case Studies for the Global Report on Human Settlements (Nairobi, Kenya: United Nations Habitat, 2003), 7.

28. Allport, "The Human," 1988.

29. J. Coleman, The House That Jack Built. Jack Mundey: Green Bans Hero (Sydney, Australia: NewSouth Books, 2016); T. Zubrycki, Waterloo (film, 1981). Accessed 30 May 2019, https://vimeo.com/159482991

30. M. Zanardo, "The Sydney Municipal Council Workers' Dwellings 1914-1927: Four Typological Case Studies in Urban Affordable Housing," in Green Fields, Brown Fields, New Fields. Proceedings of the 10th Urban History/Planning History Conference (February 7-10, 2010), eds. D. Nichols, A. Hurlimann, C. Mouat, and S. Pascoe (Melbourne, Australia: University of Melbourne Press, 2010), 648-62.

31. Ibid., 650 .

32. S. Fitzgerald, Sydney: 1842-1992 (Sydney, Australia: Hale \& Iremonger, 1992), 230.

33. Zanardo, "The Sydney Municipal," 2010.

34. Housing Commission of NSW, Waterloo Development Proposals. Analysis of Options and Environmental Impact Statement (Sydney, Australia: Housing Commission of NSW, 1976), 26.

35. M. Burgmann and V. Burgmann, Green Bans, Red Union. Environmental Activism and the New South Wales Builders Labourers' Federation (Sydney, Australia: UNSW Press, 1998), 221.

36. Ibid.

37. P. Murphy and S. Watson, Surface City. Sydney at the Millennium (Sydney, Australia: Pluto Press, 1997).

38. A. Jakubowicz, "Stranger in a Strange Land: Reflections on My First Fifty Years in Academia," Cosmopolitan Civil Societies: an Interdisciplinary Journal 10, no. 2 (2018): 1-6.

39. C. Li, "Alexandria: the Birthplace of Baby Health," in Histories of Green Square, eds. G Karskens and M. Rogowsky (Sydney, Australia: UNSW School of History and City of Sydney, 2004), 84-96.

40. A. Jakubowicz, "Celebrating 40 years-the Regional Council as a Social Movement," Inner Sydney Voice no. 130 (Spring 2016).

41. G. Karskens, "Introducing the Green Square History Project," in Histories of Green Square, eds. G. Karskens and M. Rogowsky (Sydney, Australia: UNSW School of History and City of Sydney, 2004), 9-12.

42. This study comprised a health impact assessment (HIA), a contemporary (convergent) planning and health response to ensuring that health considerations are included in planning decisions. The HIA process is modeled on the now well-established process used to review environmental concerns (environmental impact assessment), and first included in New South Wales planning legislation in 1979-see A 
Concurrent Professional Zeitgeist that Explored Composite Outcomes subsection. Somewhat ironically, the school will occupy land initially allocated for a health center-a competing interest for limited public land. When making its decision, the local council determined the health center could just as appropriately be located within commercial floor space now being constructed (https://meetings.cityofsydney.nsw.gov. au/Data/Council/20171211/Agenda/171211_COUNCIL_ITEM13.pdf).

43. J. Coleman, Housing Authorities in Urban Renewal. A Report on Research into the Role of Australian Housing Authorities in Urban Redevelopment and Renewal (Sydney, Australia: Australian Institute of Urban Studies (Project No.3) in association with The Planning Research Centre, University of Sydney, 1970).

44. P. Ashton, The Accidental City. Planning Sydney since 1788 (Sydney, Australia: Hale \& Iremonger, 1995), $10,12$.

45. Department of Environment and Planning, Sydney: Village to Metropolis. A brief Review of Planning in the Sydney Region (Sydney, Australia: Department of Environment and Planning, 1984)

46. B. Gleeson, "Sceptical Urbanism: A Rather Good Idea," address to Rethinking Suburbia seminar, City Futures Research Centre, University of New South Wales, October 18, 2006.

47. Department of Environment and Planning, Sydney: Village to Metropolis, 1984.

48. M. Darcy, "Housing: The Great Divide," in Sydney. The Emergence of a World City, ed. J. Connell (Melbourne, Australia: Oxford University Press, 2000): 222-43.

49. South Sydney City Council, South Sydney, 2001.

50. Flood, "The Case," 2003.

51. Ashton, The Accidental City, 38, 39.

52. Fitzgerald, Sydney, 228.

53. P. Spearritt and C. DeMarco, Planning Sydney's Future (Sydney, Australia: Allen \& Unwin \& NSW Department of Planning, 1988).

54. Freestone, "Historical Trajectories," 2000.

55. State Planning Authority of New South Wales, Sydney Region, 74.

56. G. Aplin, "From Colonial Village to World Metropolis" in Sydney. The Emergence of a World City, ed. J. Connell (Melbourne, Australia: Oxford University Press, 2000), 56-75, 73.

57. South Sydney City Council, Strategy for a Sustainable City of South Sydney (Sydney, Australia: South Sydney City Council, 1995), 28.

58. J. Jacobs, The Death and Life of Great American Cities (New York, NY: Random House, 1961).

59. Darcy, "Housing," 2000.

60. This observation draws on T. Butler, "Re-urbanizing London Docklands: Gentrification, Suburbanization or New Urbanism?” International Journal of Urban and Regional Research 31, no. 4 (December 2007): $759-81$.

61. Cumberland County Council, County of Cumberland, 156.

62. J. Elkington, " 25 Years Ago I Coined the Phrase 'Triple Bottom Line'. Here's Why It's Time to Rethink It," Harvard Business Review, June 25, 2018.

63. I. Serageldin and A. Sfeir-Younis, "Environment, Health, and Sustainable Development" in Effective Financing of Environmentally Sustainable Development: Proceedings of the Third Annual World Bank Conference on Environmentally Sustainable Development, eds. I. Serageldin and A. Sfeir-Younis (Washington, DC: World Bank, 1995), 101, 101-3.

64. Freestone, "Historical Trajectories," 135.

65. P. McManus, Vortex Cities to Sustainable Cities. Australia's Urban Challenge (Sydney, Australia: UNSW Press, 2005).

66. Freestone, "Historical Trajectories," 2000.

67. Fitzgerald, Sydney, 1992.

68. R. Margerum, "Implementing Integrated Planning and Management. A Typology of Approaches," Australian Planner 36, no. 3 (1999): 155-61. 
69. D. Winston, Sydney's Great experiment. The Progress of the Cumberland County Plan (Sydney, Australia: Angus \& Robinson, 1957).

70. Stretton, Ideas for Australian Cities, 1970.

71. S+T (Stanisic+Turner) in conjunction with Hassell, Green Square Structural Master Plan. (Sydney, Australia: South Sydney Council, 1997), 2.

72. https:/www.activelivingnsw.com.au/local-government/healthy-communities-and-the-ip-and-r-frame work/.

73. D. Collins and K. Burgess, "Place Management: Practice and Principles in NSW" (21st Australian and New Zealand Academy of Management Conference Proceedings, 2007); J. Mant, Place Management: Why It Works and How to Do It. Sydney Vision (UTS Papers in Planning, No. 13 Faculty of Design, Architecture and Building, University of Technology Sydney, Sydney, Australia, 1998).

74. Mant, Place Management, 1998.

75. Collins and Burgess, "Place Management," 2007.

76. G. Searle, “The Redfern-Waterloo Authority: Sydney's Continuing Use of Development Corporations as a Primary Mode of Urban Governance" (Paper to 2nd Bi-Annual State of Australian Cities [SOAC] Conference, November 30 to December 2, Brisbane, Australia, 2005).

77. World Commission on Environment and Development, Our Common Future (London, UK: Oxford University Press, 1987).

78. P. Ashton and R. Freestone, “Town Planning," Sydney Journal 1, no. 2 (June 2008): 11-23.

79. Department of Environment, Sport \& Territories, Local Agenda 21. Global-Local: Managing for the Future. A Local Government Guide (Canberra, Australia: Department of Environment, Sport \& Territories, 1994).

80. L. Contziu and C. Bagley, "Pathway to Sustainability in the South Sydney Council: The South Sydney Experience" (Paper to Pathways to Sustainability. Local initiatives for Cities and Towns. International Conference, June 1-5, Newcastle, Australia, 1997).

81. F. Baum and V. Brown, "Healthy Cities (Australia) Project: Issues of Evaluation for the New Public Health," Community Health Studies XIII, no. 2 (I989), 140-149.

82. Australian Commission for the Future, Australian Community Health Association \& Australian Local Government Association, Healthy Cities Australia: Discussion paper. Transition from pilot project to national network. (Brisbane, Australia: Healthy Cities Queensland, 1989).

83. S. Parham, "Gastronomic Strategies for Australian Cities," Urban Futures 2, no. 2 (1992).

84. T. Hancock, "Health, Human Development and the Community Ecosystem: Three Ecological Models," Health Promotion International 8, no. 1 (1993), 41-47; Healthy Development. How Landcom Plans for Healthy Places and Healthy People (Sydney, Australia: Landcom, 2010).

85. Chartered Institute of Environmental Health, Agendas for Change (London: Environmental Health Commission, Chadwick House Group, 1997).

86. V. Brown et al., Grass Roots and Common Ground. Guidelines for Community-based Environmental Health Action (Richmond, VR: Regional Integrated Monitoring Centre, University of Western Sydney, 2001 ), 5.

87. R. Freestone and E. Liu, eds., Place and Placelessness Revisited (Abingdon-on-Thames, UK: Routledge, 2016); McManus, Vortex Cities, 2005.

88. S. O'Toole, "Landcom and New Urbanism" (Paper presented to Royal Australian Institute of Architects New Urbanism Conference. November 4, Parramatta, Australia, 1996). The author was the then Chief General Manager of Landcom.

89. G. Paine and S. Thompson, Healthy Built Environment Indicators (Sydney, Australia: City Wellbeing Program, University of New South Wales, 2016).

90. Department of Infrastructure, Planning and Natural Resources, Improving Flat Design: a Progress Report (Sydney, Australia: Department of Infrastructure, Planning and Natural Resources, 2004).

91. J. Kent and A. Wheeler, "What Can Built Environment and Health Professionals Learn from Crime Prevention in Planning? Introducing HPTED," Urban Policy and Research 34, no. 1 (2016), 39-54. 
92. S. Angel, Discouraging Crime through City Planning. (Paper No. 75, Center for Planning and Development Research, University of California, Berkeley, CA, 1968); C. R. Jeffery, Crime Prevention Through Environmental Design (Beverly Hills, CA: Sage, 1971).

93. Jacobs, The Death and Life, 1961.

94. C. Gibson and J. Connell, "Artistic Dreamings: Tinseltown, Sin City and Suburban wasteland" in Sydney. The Emergence of a World City, ed. J. Connell (Melbourne, Australia: Oxford University Press, 2000), 292-318.

95. G. Saville, "Safegrowth: Moving Forward in Neighbourhood Development," Built Environment 35, no. 3 (2009): 386-402.

96. Kent and Wheeler, "What Can Built," 2016.

97. M. Hensley et al. "How Diverging Interests in Public Health and Urban Planning Can Lead to Less Healthy Cities," Journal of Planning History 19, no. 2 (2020): 71-89, 83.

98. Freestone and Wheeler, op. cit. https://uhra.herts.ac.uk/bitstream/handle/2299/7684/Gastronomic_Strate gies_for_Australian_Cities_Parham.pdf?sequence $=1$

99. Ashton, The Accidental City, 10, 12. Ashton's argument derives from his review of the City of Sydney local government area (within which Green Square is now located). It could be equally applied to the metropolitan area of Sydney as a whole, as suggested, for example, by Ashton and Freestone, "Town Planning," 11-23; J. Connell, "And the Winner Is..." in Sydney. The Emergence of a World City, ed. J. Connell (Melbourne, Australia: Oxford University Press, 2000), 1-18.

100. R. Tomlinson, Australia's Unintended Cities: The Impact of Housing on Urban Development (Canberra, Australia: CSIRO Publishing, 2012).

101. A. McCosker, "Barriers and Enablers to Healthy Planning and Active Living Initiatives" (PhD thesis, Sustainability Policy Institute, School of Design and the Built Environment, Curtin University, Perth, Australia, 2018), 69.

102. Landcom, Green Square Town Centre Master Plan (Sydney, Australia: South Sydney Development Corporation, 2003), 40.

103. Curiously the three adults portrayed are all women, and indicative of another separation attributed to the suburbs of this era — one of gender, where during the day males leave for —often distant—work locations leaving the residential area inhabited only by women and children.

104. J. Boyce, "Julian of Norwich," The Monthly, August 2020, 44-45.

105. Karskens, "Introducing the Green Square," 2004.

106. Freestone and Hutchings, "Planning History," 72-91, 73, 83; McManus, Vortex Cities, 2005.

107. McManus, Vortex Cities, 2005.

108. Kent and Thompson, "The Three Domains of Urban Planning," 239-256; B. Poland, G. Krupa and D. McCall, "Settings for Health Promotion: An Analytic Framework to Guide Intervention Design and Implementation," Health Promotion Practice 10, no. 4 (2009): 505-516.

109. Freestone and Hutchings, "Planning History," 83.

110. This suggestion of a contemporary "hubris" is also prompted by the otherwise frequent and inherent close connection between health and the planning of urban areas throughout history. A good summary is provided by Freestone and Wheeler, 2015, op. cit. A useful list of references to other reviews is also provided by Hensley et al., "How Diverging Interests," 2020.

111. South Australia Health, "Health in All Policies. Adelaide 2010 International Meeting", Public Health Bulletin SA 7, no. 2, July 2010. https://www.sahealth.sa.gov.au/wps/wcm/connect/public +content/ $\mathrm{sa}+$ health + internet/about + us/about $+\mathrm{sa}+$ health/health + in + all + policies

112. The Health Impact Statement for Green Square (Note 43) was for example undertaken some fifteen years after the initial planning. The "Three Healths Framework" (Table 3) developed as part of this Project provides a useful comprehensive list of contemporary influences on human health. 
113. Although this Project has been about enabling the inclusion of health considerations within higher density development, this process needs to be two way: the wider urban consolidation imperative suggests a need to also graft those denser health-supportive aspects onto existing and still proposed low-density suburbs.

\section{Author Biographies}

Greg Paine is a researcher with the City Wellbeing Program, City Futures Research Centre at the University of New South Wales. He is keen to use his previous extensive experience as a practicing town planner to assist the translation of research into practice.

Susan Thompson is a professor of planning, School of Built Environment, University of New South Wales, Sydney, Australia. She leads the City Wellbeing Program in the City Futures Research Centre.

Jason Prior is a professor of planning, Health and Environment at the Institute for Sustainable Futures, University of Technology Sydney. As an architect and planner, Jason's program of research focuses on urbanization, governance, and health and well-being.

Irena Connon is a research fellow at the University of Dundee and a fellow of the Higher Education Academy. Her research interests are in the human responses to environmental hazards, disasters, and climate risks; urban geography; sustainable development and healthy urban planning; planetary health; and transdisciplinary research methodologies.

Jennifer L. Kent is a senior research fellow in the Urbanism Program at the Sydney University School of Architecture, Design and Planning. Her research interests are at the intersections between urban planning, transport, and human health, with specialization in combining quantitative and qualitative data with understandings from policy science to trace the practical, cultural, and political barriers to healthy cities. 